\title{
Development of Chicken Immunoglobulin $Y$ for Rapid Detection of Cronobacter muytjensii in Infant Formula Powder
}

\author{
Yesol Kim, Shruti Shukla ${ }^{1}$, Maruf Ahmed, Seokmin Son², Myunghee Kim¹, and Sejong Oh* \\ Division of Animal Science, Chonnam National University, Gwangju 500-757, Korea \\ ${ }^{1}$ Department of Food Science and Technology, Yeungnam University, Gyeongsan 712-749, Korea \\ ${ }^{2}$ School of Food Science, Seowon University, Cheongju 361-742, Korea
}

\begin{abstract}
The present study was aimed to produce a chicken polyclonal antibody against Cronobacter muytjensii and to develop an immunoassay for its detection. Purification of anti-C. muytjensii IgY from egg yolk was accomplished using various methods such as water dilution and salt precipitation. As a result, sodium dodecyl sulfate-polyacrylamide gel electrophoresis produced two bands around 30 and $66 \mathrm{kDa}$, corresponding to a light and a heavy chain, respectively. Indirect competitive enzyme-linked immunosorbent assay (IC-ELISA) was performed to determine the effectiveness of the chicken IgY against C. muytjensii. The optimum conditions for detecting C. muytjensii by indirect ELISA and checkerboard titration of the antigen revealed an optimum average absorbance at the concentration of $18 \mu \mathrm{g} / \mathrm{mL}$, having ca. $10^{8}$ coated cells per well. The anti-C. muytjensii IgY antibody had high specificity for $C$. muytjensii and low cross-reactivity with other tested pathogens. In this assay, no cross-reactivity was observed with the other genera of pathogenic bacteria including Escherichia coli O157:H7, Salmonella Typhimurium, Staphylococcus aureus, Bacillus cereus, Enterobacter aerogenes, Salmonella Enteritidis and Listeria monocytogenes. In addition, detection of $C$. muytjensii in infant formula powder showed a low matrix effect on the detection curve of IC-ELISA for C. muytjensii, with similar detection limit of $10^{5} \mathrm{CFU} / \mathrm{mL}$ as shown in standard curve. These findings demonstrate that the developed method is able to detect $C$. muytjensii in infant formula powder. Due to the stable antibody supply without sacrificing animals, this $\operatorname{IgY}$ can have wide applications for the rapid and accurate detection of $C$. muytjensii in dairy foods samples.
\end{abstract}

Key words: enzyme-linked immunosorbent assay, egg yolk, Cronobacter muytjensii, IgY, pathogen detection, infant formula powder

\section{Introduction}

Enterobacteriaceae are Gram-negative bacilli that normally inhabit the intestine of animals. Although most of the species are harmless, some of them produce exotoxins. Particularly, Cronobacter muytjensii is one of the newly classified microorganisms from Enterobacter sakazakii group (Iversen and Forsythe, 2003). C. muytjensii is usually found in powdered milk and is an opportunistic pathogen that causes meningitis, septicemia and necrotizing enterocolitis in neonates and small children (Iversen and Forsythe, 2003). C. muytjensii is an extremely harmful microorganism and is associated with a mortality rate of $40-80 \%$ among infants (Lai, 2001). C. muytjensii has been isolated from plant foods and food ingredients such

*Corresponding author: Sejong Oh, Division of Animal Science, Chonnam National University, Gwangju 500-757, Korea. Tel: 8262-530-2116, Fax: 82-62-530-2129, E-mail: soh@chonnam.ac.kr as cereal, fruits, vegetables, legume products and animal origin foods like milk, meat and fish, which poses a serious threat to the food and medical industries (Friedemann, 2007).

C. muytjensii is usually detected on tryptic soy agar, and its colonies are developed as a yellow pigment. However, Druggan-Forsythe-Iversen medium has been recently used to detect $C$. muytjensii (Bar-Oz et al., 2001; Iverson and Forsythe, 2003). Various other methods such as DNA hybridization, polymerase chain reaction, immunomagnetic beads and immunoenzymatic assays have been used to detect $C$. muytjensii in various food matrices (Schneid et al., 2006). The enzyme-linked immunosorbent assay (ELISA) has been shown to be a sensitive technique for the detection of several infectious agents (Voller and Bidwell, 1976). ELISAs are considered as useful tools to detect and quantify the immunological reactions and have several advantages such as rapidity, potent mobility, better convenience, higher sensitivity and efficiency for 
detecting the pathogens at low detection limit (Liu et al., 2010). In contrast, nowadays, the demand for immunoglubulin (IgY) is increasing not only for immunological purposes but also for therapeutic applications (Carlander et al., 2003). Chicken egg yolk is a valuable and inexpensive source of polyclonal antibodies, and large amount of IgY can be extracted from the eggs of immunized chickens (Kovacs-Nolan and Mine, 2004). Previously, a polyclonal antibody against bbb-cyclocitral has been isolated from chicken eggs (Munene, 2004).

To the best of our knowledge, no several studies have been conducted so far on the production of a polyclonal antibody against $C$. muytjensii and its detection by using an ELISA. Therefore, the principal objectives of this study were to prepare a specific polyclonal antibody (IgY) against $C$. muytjensii and to develop an ELISA in order to determine the effectiveness of developed anti- $C$. muytjensii $\mathrm{IgY}$ in infant formula powder.

\section{Materials and Methods}

\section{Reference strains and selective media}

The bacterial pathogens such as Cronobacter muytjensii ATCC51329, Escherichia coli O157:H7 ATCC43895, Enterobacter aerogenes ATCC15038, Salmonella Typhimurium ATCC13311, Salmonella Enteritidis ATCC4931, Staphylococcus aureus ATCC10832, Bacillus cereus ATCC14579 and Listeria monocytogenes KCTC3596 were collected from the American Type Culture Collection and the Korean Collection for Type Culture. $C$. muytjensii, E. coli $\mathrm{O} 157: \mathrm{H} 7$ and E. aerogenes were grown in tryptic soy broth (TSB; Difco, Franklin Lakes, NJ, USA), whereas Bacillus spp., Salmonella spp. and $S$. aureus were grown in nutrient broth (NB, Difco, USA).

\section{Animals}

Animal use protocol was in accordance with international standard on the care and use of experimental animals (Canadian Council on Animal Care, 1993). Brown Leghorn chickens (25 wk old) were used for the experimental purpose. Animals were fed with standard pellet diet and housed under the following standard conditions: temperature $\left(25^{\circ} \mathrm{C}\right)$, humidity $(55 \%)$ and light/dark cycles (12 h/12 h).

\section{Reagents and materials}

Goat anti-chicken IgY-horseradish peroxidase (HRP) and chicken IgY (positive control in purity test) were provided by Santa Cruz Biotechnology (USA) and Promega
(USA), respectively. Freund's complete and incomplete adjuvants were obtained from Sigma-Aldrich (USA). All chemicals including 3,3',5,5'-tetramethylbenzidine (TMB), sodium carbonate and sodium hydrogen carbonate were purchased from Sigma-Aldrich. Phosphate-buffered saline (PBS, pH 7.0), consisting of $138 \mathrm{mM} \mathrm{NaCl}, 1.5 \mathrm{mM}$ $\mathrm{KH}_{2} \mathrm{PO}_{4}, 7 \mathrm{mM} \mathrm{Na}_{2} \mathrm{HPO}_{4}$ and $2.7 \mathrm{mM} \mathrm{KCl}$, and carbonate buffer $\left(15 \mathrm{mM} \mathrm{Na}_{2} \mathrm{CO}_{3}, 35 \mathrm{mM} \mathrm{NaHCO}_{3}\right)$ were prepared in the laboratory for this study.

\section{Antigen preparation}

For antigen preparation, C. muytjensii ATCC51329 was cultivated in TSB at $37^{\circ} \mathrm{C}$ for $18 \mathrm{~h}$ with shaking. The cells were harvested after cultivation by centrifugation at 3,000 $g$ for $10 \mathrm{~min}$. The collected cells were washed thrice with $0.01 \mathrm{M}$ PBS ( $\mathrm{pH} 7.0$ ), mixed with equal volume of 0.01 M PBS (pH 7.0) and fragmented by sonication (Sonics \& Materials Inc., USA). The cellular material was removed by centrifugation at $3,000 \mathrm{~g}$ for $10 \mathrm{~min}$, and the supernatant (C. muytjensii whole cell lysate) was collected (Park et al., 2012) to measure the protein concentration using the Bradford method (Bradford, 1976).

\section{Immunization}

To produce chicken anti-C. muytjensii IgY, brown Leghorn chickens were immunized intramuscularly with $C$. muytjensii whole cell lysate $(0.5 \mathrm{~mL})$ using an equal volume of Freund's complete adjuvant as described previously (Lee et al., 2002) with some modifications. Chickens were injected at four different sites $(0.25 \mathrm{~mL}$ per site) of the leg muscle. Three booster injections with Freund's incomplete adjuvant were given at two weeks interval following the first injection. After one month of immunization, the eggs laid were collected daily for $30 \mathrm{~d}$ and stored at $4^{\circ} \mathrm{C}$. Egg yolk was separated, pooled and stored at $-20^{\circ} \mathrm{C}$ prior to purification step.

\section{Purification and preparation of egg yolk antibody}

In the present study, four different methods were used for the purification of the egg yolk IgY, which were compared from each other for better purification efficacy.

1. In the first method, the purification of chicken antiC. muytjensii IgY was performed by water dilution and salt precipitation methods (Hansen et al., 1998). The egg yolk was separated, washed with distilled water, diluted 10 times with $3 \mathrm{mM} \mathrm{HCl}$, adjusted to give the desired $\mathrm{pH}$ 5.0 with $10 \%$ acetic acid and then kept at $4^{\circ} \mathrm{C}$ for $6 \mathrm{~h}$. Following the centrifugation at $10,000 \mathrm{~g}$ at $4^{\circ} \mathrm{C}$ for 15 min, the supernatant was collected. Further, ammonium 
sulfate was added to the supernatant in the ratio of $6: 4$ (supernatant:ammonium sulfate) and stirred for $15 \mathrm{~min}$. The pellet was again collected by centrifugation at 10,000 $g$ for $15 \mathrm{~min}$ at $4^{\circ} \mathrm{C}$. Finally, the pellet containing the $\operatorname{IgY}$ was collected and dissolved in $0.01 \mathrm{M}$ PBS (pH 7.0) with an equal quantity of egg yolk's initial volume.

2. In the second method, the purification of chicken anti-C. muytjensii $\operatorname{IgY}$ was performed according to the developed procedure of Akita and Nakai (1992). Briefly, egg yolk was separated from the white proportion of the egg and diluted with distilled water (acidified with $0.1 \mathrm{~N}$ $\mathrm{HCl}$, predetermined to give the desired $\mathrm{pH}$ 5.0). The supernatant was collected after centrifugation of the egg yolk at $10,000 \mathrm{~g}$ for $60 \mathrm{~min}$ at $4^{\circ} \mathrm{C}$. Further, collected supernatant and saturated ammonium sulfate were mixed (6:4), and this mixture was centrifuged at $10,000 \mathrm{~g}$ for 60 $\min$ at $4^{\circ} \mathrm{C}$. The pellet obtained was washed with $14 \%$ sodium sulfate and centrifuged at $10,000 \mathrm{~g}$ for $60 \mathrm{~min}$. The precipitate containing IgY was obtained and dissolved in $0.01 \mathrm{M}$ PBS with a quantity of half of the initial volume.

3. In the third modified-water dilution method, the separated yolk was diluted nine-times with distilled water and acidified with $0.1 \mathrm{~N} \mathrm{HCl}$ to adjust the $\mathrm{pH}$ at 5.0 (Akita and Nakai, 1993). The supernatant was collected after centrifugation of the egg yolk at $10,000 \mathrm{~g}$ for $25 \mathrm{~min}$ at $4^{\circ} \mathrm{C}$. Further, to the supernatant, $19 \%$ sodium sulfate was added slowly, and the mixture was kept at room temperature for $2 \mathrm{~h}$. The supernatant was discarded after centrifuging at $10,000 \mathrm{~g}$ for $25 \mathrm{~min}$ at $4^{\circ} \mathrm{C}$, and the precipitate containing the IgY was dissolved in $0.01 \mathrm{M}$ PBS (pH 7.0) with an equal quantity of egg yolk's initial volume.

4. The fourth method was adopted from Wallmann et al. (1990). Briefly, egg yolk was separated from the white proportion of the egg, diluted five-times with distilled water and incubated at $-20^{\circ} \mathrm{C}$ for $72 \mathrm{~h}$. The supernatant was collected after centrifugation at $2,800 \mathrm{~g}$ for $20 \mathrm{~min}$ at room temperature. Then, $0.27 \mathrm{~g} / \mathrm{mL}$ ammonium sulfate was added to the supernatant and allowed to stir at room temperature for $2 \mathrm{~h}$. The centrifugation step was re-performed at 2,800 $\mathrm{g}$ for $20 \mathrm{~min}$ at room temperature. Finally, a precipitate containing $\operatorname{IgY}$ was obtained and dissolved in $5 \mathrm{~mL}$ PBS/egg yolk $\mathrm{mL}$.

\section{Sodium dodecyl sulfate-polyacrylamide gel electro- phoresis (SDS-PAGE)}

The purity of various IgY preparations was checked using SDS-PAGE (Atto, Japan) under reduced conditions as described by Laemmli (1970) with some modifications. A polyacrylamide stacking gel $(4 \%, \mathrm{w} / \mathrm{v})$ and a separating gel $(15 \%, \mathrm{w} / \mathrm{v})$ were used to separate the distinct proteins into bands. Briefly, the samples were mixed with digestion buffer containing 5\% 2-mercaptoethanol (v/v) and then heated for $3 \mathrm{~min}$ at $100^{\circ} \mathrm{C}$. Electrophoresis was conducted at a constant voltage of $20 \mathrm{~mA}$ at room temperature. Purity and recovery of chicken anti-C. muytjensii IgY were monitored at various stages by SDS-PAGE.

\section{Measurement of antibody titer by ELISA}

Formalin treated whole $C$. muytjensii cells were diluted in $0.01 \mathrm{M}$ carbonate buffer ( $\mathrm{pH} 9.6$ ) to adjust $10^{7}$ cells/ $\mathrm{mL}$. A $100 \mu \mathrm{L}$ of the cell suspension $\left(10^{7}\right.$ cells $\left./ \mathrm{mL}\right)$ was coated onto a 96-well microtitier plate (Maxisorp, CA) for $24 \mathrm{~h}$ at $4^{\circ} \mathrm{C}$, after which the plate was washed three times with $0.01 \mathrm{M}$ PBS (pH 7.0) and then blocked with $200 \mu \mathrm{L}$ of $5 \%(\mathrm{w} / \mathrm{v})$ skim milk for $1 \mathrm{~h}$ at $37^{\circ} \mathrm{C}$. The plate was then washed three times with $0.01 \mathrm{M}$ PBS containing $0.05 \%(\mathrm{v} / \mathrm{v})$ Tween 20 (PBST). An appropriately diluted primary antibody (chicken anti-C. muytjensii IgY) solution $(100 \mu \mathrm{L})$ was added to the wells, followed by incubation at $4^{\circ} \mathrm{C}$ for $24 \mathrm{~h}$. The plate was rewashed with PBST, and then $100 \mu \mathrm{L}$ of an appropriately diluted secondary antibody (goat anti-chicken IgY-HRP) solution was added, followed by incubation at $37^{\circ} \mathrm{C}$ for $1 \mathrm{~h}$. After that, the plate was rewashed five times with PBST, and $50 \mu \mathrm{L}$ of TMB was added to each well, followed by incubation at $37^{\circ} \mathrm{C}$ for $30 \mathrm{~min}$. In order to stop the reaction, 50 $\mu \mathrm{L}$ of $1 \mathrm{~N}$ hydrochloric acid $(\mathrm{HCl})$ was added to each well, and then absorbance was measured at $450 \mathrm{~nm}$ using an ELISA plate reader (Tecan, Infinite M200, Switzerland). Each experiment was performed in triplicates.

\section{Assay format}

The indirect competitive enzyme linked immunosorbent assay (IC-ELISA) method was adopted for this assay with slight modifications (Engvall and Perlmann, 1971). Briefly, formalin treated whole $C$. muytjensii cells were coated onto a 96-well microtitier plate, after which the plate was washed three times with $0.01 \mathrm{M}$ PBS (pH 7.0) and then blocked with $200 \mu \mathrm{L}$ of $5 \%$ (w/v) skim milk for $1 \mathrm{~h}$ at $37^{\circ} \mathrm{C}$. The plate was then rewashed with PBST. An appropriately diluted primary antibody (chicken anti- $C$. muytjensii $\operatorname{IgY})$ solution $(50 \mu \mathrm{L})$ was mixed with cultured C. muytjensii cells $(50 \mu \mathrm{L})$. From the mixture, a $100 \mu \mathrm{L}$ solution was added in each well, and the plate was incubated at $37^{\circ} \mathrm{C}$ for $1 \mathrm{~h}$. The plate was again washed with PBST, and then an appropriately diluted solution (100 
$\mu \mathrm{L}$ ) of secondary goat anti-chicken IgY-HRP was added to each well. After the plate was incubated at $37^{\circ} \mathrm{C}$ for 1 $\mathrm{h}$, the plate was rewashed with PBST, and $50 \mu \mathrm{L}$ of TMB was added to each well, followed by incubation at $37^{\circ} \mathrm{C}$ for $30 \mathrm{~min}$. In order to stop the reaction, $50 \mu \mathrm{L}$ of $1 \mathrm{~N}$ $\mathrm{HCl}$ was added to each well, and then absorbance was measured at $450 \mathrm{~nm}$ using an ELISA plate reader. Each experiment was performed in triplicates.

\section{Optimization and construction of standard curve for IC-ELISA}

Optimization of IC-ELISA assay was conducted by using checkerboard test. An IC-ELISA requires the competition between IgY and C. muytjensii. Briefly, for optimization, the plate was coated with primary antibody (chicken anti-C. muytjensii $\mathrm{IgY}$ ) at various concentrations of $0.018 \mu \mathrm{g} / \mathrm{mL}, 0.18 \mu \mathrm{g} / \mathrm{mL}, 1.8 \mu \mathrm{g} / \mathrm{mL}, 18 \mu \mathrm{g} / \mathrm{mL}$ and $180 \mu \mathrm{g} / \mathrm{mL}$. Then, $C$. muytjensii at various concentrations of $10^{5}-10^{8}$ cells $/ \mathrm{mL}$ was added for the reaction to occur at $4^{\circ} \mathrm{C}$ for overnight, and values were determined by measuring the absorbance at $450 \mathrm{~nm}$. In order to construct standard curve for the developed IC-ELISA, various parameters such as antibody concentrations, blocking buffer, incubation time and temperature were optimized. Finally, the standard curve was constructed on the basis of optimal conditions.

\section{Specificity test}

The cross-reactivity of developed antibody was evaluated by IC-ELISA using the following pathogenic strains such as E. coli O157:H7 (ATCC43895), E. aerogenes (ATCC15038), S. Typhimurium (ATCC13311), S. Enteritidis (ATCC4931), S. aureus (ATCC10832), B. cereus (ATCC14579) and L. monocytogenes (KCTC3596).

\section{Detection of $C$. muytjensii in infant formula powder}

After adding pure cultures of $C$. muytjensii to the infant formula powder, the concentration of $C$. muytjensii was determined using the IC-ELISA technique developed in this study. Briefly, a $25 \mathrm{~g}$ of infant formula powder was mixed with $225 \mathrm{~mL}$ of TSB at $\mathrm{pH}$ 7.0. Pure cultures of $C$. muytjensii were cultured in TSB at $37^{\circ} \mathrm{C}$ for $18 \mathrm{~h}$. A $1 \%$ serially diluted $C$. muytjensii pure culture was added into infant formula powder solution, and the IC-ELISA method was employed to determine the concentration of $C$. muytjensii in infant formula powder. In parallel, an equal volume of TBS buffer mixed with serially diluted the pure culture of $C$. muytjensii served as a positive control, whereas only TBS served as a negative control.

\section{Results and Discussion}

\section{Measurement of antibody titer}

The chicken anti-C. muytjensii IgY was harvested from chicken egg yolk. Fig. 1 shows the immune response against $C$. muytjensii whole cell lysate. Measurement of the antibody titer for 11 wk resulted in the high antibody titer value, starting to significant increase from $4^{\text {th }} \mathrm{wk}$, and the highest activity of IgY was found on $9^{\text {th }}$ wk which was measured by ELISA (Fig. 1). Calzado et al. (2001) reported that the IgY level was highest at $4 \mathrm{wk}$ and remained stable for up to $7 \mathrm{wk}$.

\section{SDS-PAGE analysis}

Purification of IgY from egg yolk was performed by four different methods such as pure water dilution and salt precipitation methods (Akita and Nakai, 1992; Akita and Nakai, 1993; Wallmann et al., 1990; Hansen et al., 1998). Purification of anti-C. muytjensii IgY was confirmed by SDS-PAGE analysis using purified chicken IgY as control. The most effective method to purify the IgY was found to be the water dilution method. By using all purification methods, two strong bands around 30 and $66 \mathrm{kDa}$ were produced (Fig. 2). Akita and Nakai (1992) method produced the highest yield without non-specific proteins (lane 2 in Fig. 2) and had no adverse effects on IgY immunoactivity (data not shown). Therefore, further experiments were conducted using this purified antibody (IgY) by the method of Akita and Nakai (1992).

\section{Optimal conditions for detecting $C$. muytjensii}

The optimal purified antibody concentration and the antigen coating concentration were assessed by using the

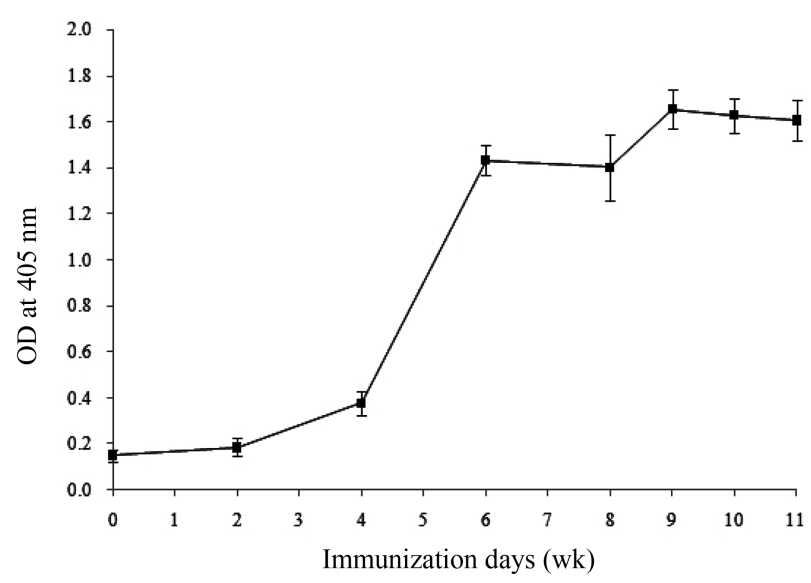

Fig. 1. Production profile of immunoglobuin $Y$ in the eggs of immunized chickens. 


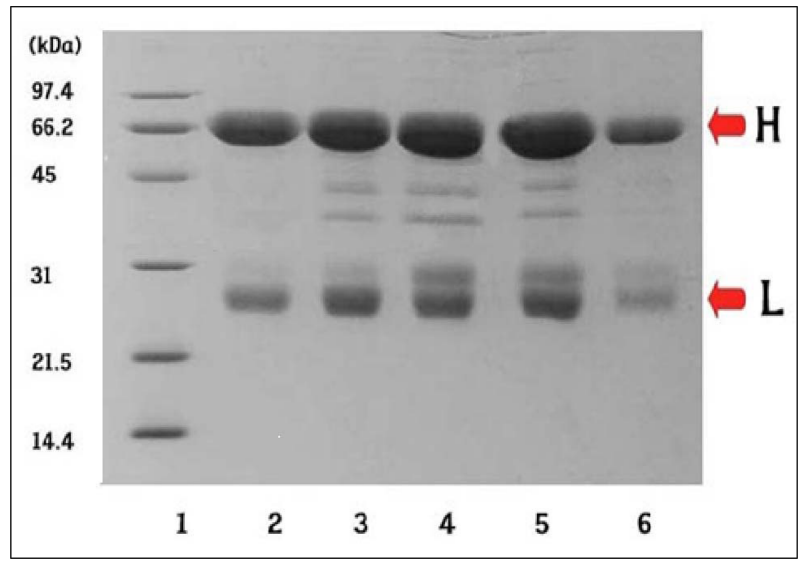

Fig. 2. SDS-PAGE patterns of purified IgY from egg yolk. Lane 1, low-range standard marker; lane 2, Akita and Nakai (1992); lane 3, Hansen et al. (1998); lane 4, Akita and Nakai (1993); lane 5, Wallmann et al. (1990); lane 6, chicken IgY (control); H, heavy chain; L, light chain.

checkerboard test. A final concentration of $0.5 \%$ formalin was added to the $C$. muytjensii culture medium, followed by overnight incubation at $4^{\circ} \mathrm{C}$. Coating concentrations of $10^{5}-10^{8}$ cells/well and $0.018-180 \mu \mathrm{g} / \mathrm{mL}$ of purified $\operatorname{IgY}$ was used in the ELISA. As results, 100-1000 fold IgY dilution (1.8-18 $\mu \mathrm{g} / \mathrm{mL})$ and $10^{7}-10^{8}$ coated cells exhibited significant absorbance (Fig. 3a and 3b). Previously, 40-fold and 1000-fold diluted Salmonella gallinarum and Enterobacter muytjensii antibodies have been used for the detection of Salmonella and Enterobacter by Prakash and Suryanarayana (2005), respectively. In our study, $\operatorname{IgY}$ dilution was slightly different from the antibody dilutions used by Prakash and Suryanarayana (2005). However, whole cell coating concentrations were similar with those of Prakash and Suryanarayana (2005).

Furthermore, to optimize the secondary antibody (goat anti-chicken IgY-HRP) concentration, the secondary antibody solutions of $0.032 \mu \mathrm{g} / \mathrm{mL}, 0.04 \mu \mathrm{g} / \mathrm{mL}, 0.053 \mu \mathrm{g} /$ $\mathrm{mL}$ and $0.08 \mu \mathrm{g} / \mathrm{mL}$ were made with $5 \%$ non-fat dry milk. Fig. 4 shows that the binding of the secondary antibody to the antigen-antibody complex (C. muytjensii-IgY) was higher at $0.08 \mu \mathrm{g} / \mathrm{mL}$, compared to other antibody concentrations. However, the antibody concentrations of $0.04 \mu \mathrm{g} / \mathrm{mL}$ or $0.053 \mu \mathrm{g} / \mathrm{mL}$ were considered economical.

Fig. 5 shows the $C$. muytjensii ELISA standard curve, and the optimal conditions for IC-ELISA to detect $C$. muytjensii has been described in Table 1 . In brief, coating antigen $\left(10^{8}\right.$ formalin killed cells of C. muytjensii/well) was coated at $37^{\circ} \mathrm{C}$ for $1 \mathrm{~h}$. An appropriate response was found with the secondary antibody at the concentration of $0.04 \mu \mathrm{g} / \mathrm{mL}$ at $37^{\circ} \mathrm{C}$ for $1 \mathrm{~h}$, and the enzyme substrate reaction was continued at $37^{\circ} \mathrm{C}$ for $30 \mathrm{~min}$.
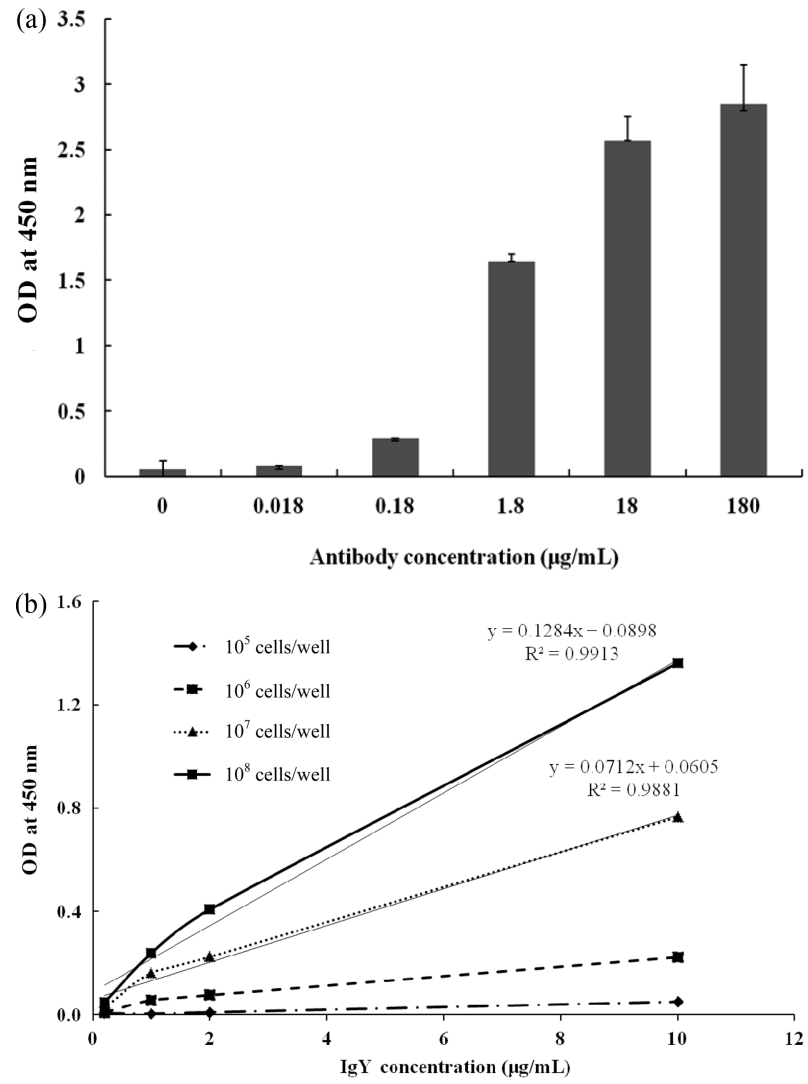

Fig. 3. Checkerboard titration curve.

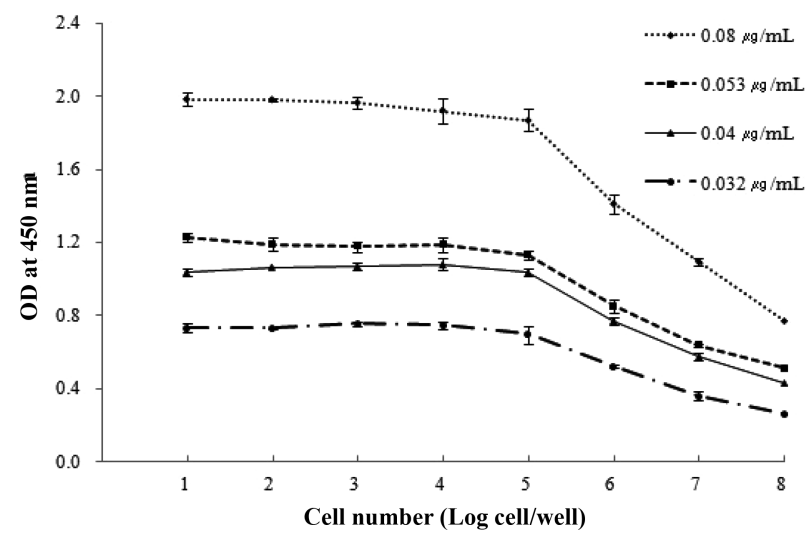

Fig. 4. Effect of secondary antibody (goat anti-chicken IgYHRP) concentration.

\section{IgY specificity test}

The specificity of the developed chicken anti-C. muytjensii IgY was evaluated using a variety of foodborne pathogens including E. coli $\mathrm{O} 157: \mathrm{H} 7, S$. Typhimurium, $S$. Enteritidis, S. aureus, B. cereus and L. monocytogenes. The results revealed that IC-ELISA was found sensitive only against $C$. muytjensii with detection sensitivity of $10^{5}$ cells $/ \mathrm{mL}$ and showed no cross-reactivity with other tested bacteria (Fig. 6). In our study, these values were found to be useful for comparing the detection limit of Crono- 


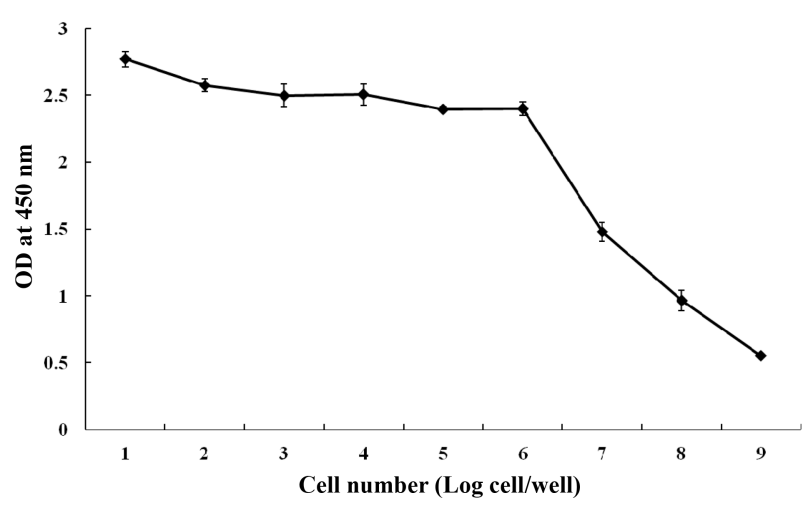

Fig. 5. IC-ELISA standard curve for Cronobacter muytjensii.

bacter using sandwich ELISA. Park et al. (2012) also observed similar findings for $C$. muytjensii by using the developed sandwich ELISA. In addition, Baumgartner et al. (2009) reported $2.9 \times 10^{7} \mathrm{CFU} / \mathrm{g}$ as the detection limit of Cronobacter using a pulsed field electrophoresis assay method. Hochel and Skvor (2009) also reported similar findings on the lack of cross-reactivity when they tested the developed immunoassay with other bacterial species. Thus, this study confirmed that the developed immunoassay for C. muytjensii is sensitive and specific to C. muytjensii and can detect this organism within $24 \mathrm{~h}$, as compared to conventional culture-dependent methods which require 5 to 7 days for Cronobacter detection.

\section{Detection of $\boldsymbol{C}$. muytjensii in infant formula powder}

In this study, we developed an immunoassay technique for the detection of $C$. muytjensii in commercial food products such as infant formula powder. Fig. 7 shows the detection curve for $C$. muytjensii in infant formula powder using IC-ELISA. The results for the detection of $C$. muytjensii in infant formula powder showed a low matrix effect as compared with the detection curve of Fig. 5. Although signals obtained by using infant formula powder did show this minor matrix effect, the response curve (Fig. 7) still showed dose dependent characteristics, similar to the standard curve obtained without using infant formula powder (Fig. 5). Park et al. (2012) also reported

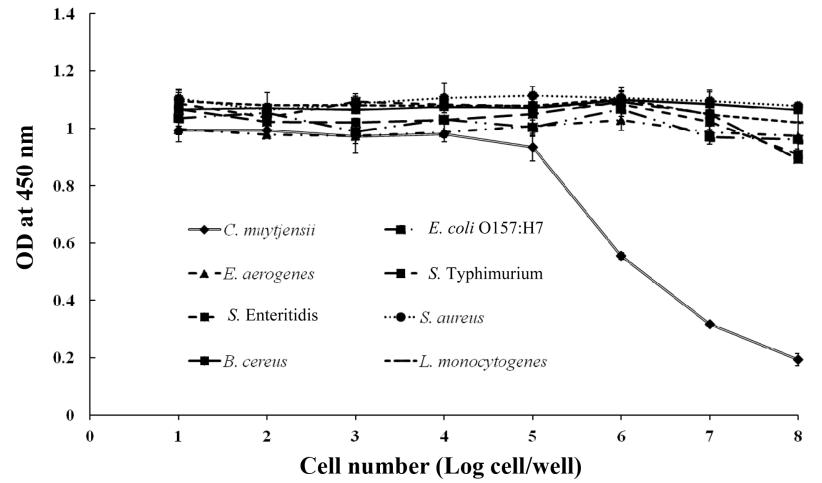

Fig. 6. Cross-reactivity with other genus of pathogenic bacteria.

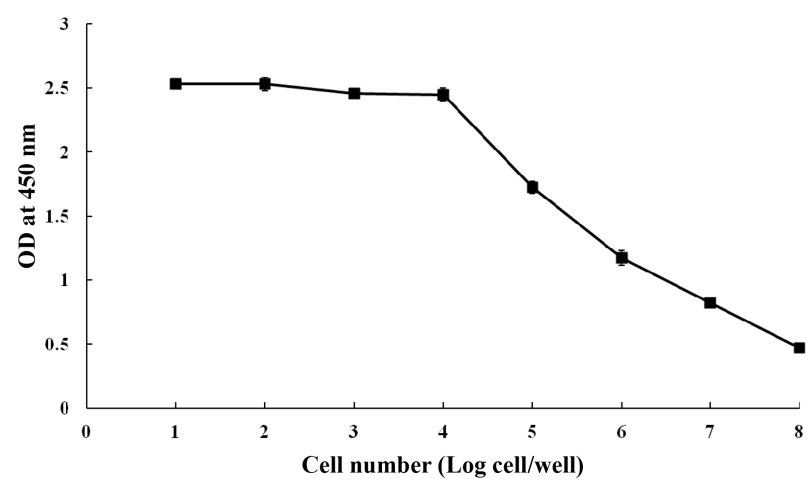

Fig. 7. Detection of Cronobacter muytjensii in infant formula powder by using IC-ELISA.

similar results when they developed the sandwich ELISA for the detection of $C$. muytjensii in infant formula powder.

The developed antibody (chicken anti-C. muytjensii $\operatorname{IgY)}$ was found to be very specific to C. muytjensii and was able to detect the $C$. muytjensii in pure culture and commercial food sample (infant formula powder) with the detection limit of $10^{4}-10^{5} \mathrm{CFU} / \mathrm{mL}$ (Figs. 5 and 7). This result confirms the potential efficacy of our immunological assays for the purpose of developing new and effective pathogen detection methods. Hence, it is concluded that the developed ELISA may provide a better alternative than conventional identification methods for detecting C. muytjensii not only in infant formula powder

Table 1. Optimal condition for the Cronobacter muytjensii detection by using IC-ELISA

\begin{tabular}{ll}
\hline \multicolumn{1}{c}{ Item } & \multicolumn{1}{c}{ Conditions } \\
\hline Antigen coating & Formallin killed cells of $C$. muytjensii $\left(10^{8}\right.$ cell/well) at $37^{\circ} \mathrm{C}$ for $1 \mathrm{~h}\left(\right.$ or $4^{\circ} \mathrm{C}$, overnight) \\
Blocking condition & $5 \%$ Skim milk at $37^{\circ} \mathrm{C}$ for $1 \mathrm{~h}$ \\
Primary antibody & IgY $(18 \mu \mathrm{g} / \mathrm{mL})$ \\
Secondary antibody & Goat anti-chicken $\mathrm{IgY}-\mathrm{HRP}(0.04 \mu \mathrm{g} / \mathrm{mL})$ at $37^{\circ} \mathrm{C}$ for $1 \mathrm{~h}$ \\
Substrate & $3,3^{\prime}, 5,5^{\prime}-$ Tetramethylbenzidine at $37^{\circ} \mathrm{C}$ for $30 \mathrm{~min}$ \\
Washing solution & $0.01 \mathrm{M} \mathrm{PBS} \mathrm{(containing} 0.14 \mathrm{M} \mathrm{NaCl})+0.05 \%$ Tween 20 \\
\hline
\end{tabular}


but also in other food samples.

\section{Acknowledgements}

This study was supported by the Korea Research Foundation (KRF-2007-F00051) and the National Research Foundation (NRF) grant to the Korea government (MEST) (R01-2008-000-20593-0).

\section{References}

1. Akita, E. M. and Nakai, S. (1992) Immunoglobulins from egg yolk: isolation and purification. J. Food Sci. 57, 629634.

2. Akita, E. M. and Nakai, S. (1993) Comparison of four purification methods for the production of immunoglobulin from eggs laid by hens immunized with an enterotoxigenic $E$. coli strain. J. Immunol. Methods 160, 207-262.

3. Bar-Oz, B., Preminger, A., Peleg, O., Block, C., and Arad, I. (2001) Enterobacter muytjensii infection in the newborn. Acta Paediatr. 90, 356-358.

4. Baumgartner, A., Grand, M., Liniger, M., and Iversen, C. (2009) Detection and frequency of Cronobacter spp. (Enterobacter sakazakii) in different categories of ready-to-eat foods other than infant formula. Int. J. Food Microbiol. 136, 189-192.

5. Bradford, M. M. (1976) A rapid and sensitive method for quantitation of microgram quantities of protein utilizing the principle of protein-dye-binding. Anal. Biochem. 72, 248254.

6. Calzado, E. G., Garrido, R. M., and Schade, R. (2001) Human haemoclassification by use of specific yolk antibodies obtained after immunization of chickens against human group antigen. Alter. Lab Animal 29, 717-726.

7. Canadian Council on Animal Care (1993) Guide to the care and use of experimental animals. Downloaded from http:// www.ccac.ca/ on 6/1/2011.

8. Carlander, D., Wilhelmson, M., and Larsson, A. (2003) Immunoglobulin Y levels in egg yolk from three chicken genotypes. Food Agric. Immunol. 15, 35-40.

9. Engvall, E. and Perlmann, P. (1971) Enzyme-linked immunosorbent assay (ELISA): quantitative assay of immunoglobulin G. Immunochem. 8, 871-874.

10. Friedemann, M. (2007) Enterobacter muytjensii in food and beverages (other than infant formula and milk powder). Int. J. Food Microbiol. 116, 1-10.

11. Hansen, P., Scoble, J. A., Hanson, B., and Hoogenraad, N. J. (1998) Isolation and purification of immunoglobulins from chicken eggs using thiophilic interaction chromatography. $J$. Immunol. Methods 215, 1-7.

12. Hochel, I. and Skvor, J. (2009) Characterization of antibodies for the immunochemical detection of E. sakazakii. Czech J. Food Sci. 27, 66-74.

13. Iverson, C. and Forsythe, S. J. (2003) Risk profiles of Enterobacter muytjensii, an emergent pathogen associated with infant milk formula. Trends Food Sci. Tech. 14, 443-454.

14. Kovacs-Nolan, J. and Mine, Y. (2004) Avian egg antibodies: basic and potential applications. Avian Poultry Biol. Rev. 15, 25-46.

15. Laemmli, U. K. (1970) Cleavage of structural proteins during the assembly of the head of bacteriophage T4. Nature 227, 680-685.

16. Lai, K. K. (2001) Enterobacter sakazakii infections among neonates, infants, children, and adults: case reports and a review of the literature. Medicine 80, 113-122.

17. Lee, A. K., Chang, K. S., Lee, J. Y. Lee, H. J., and Koo, S. N. (2002) Acid stability of anti-Helicobacter pyroli IgY in aqueous polyol solution. J. Biochem. Mol. Biol. 35, 488-493.

18. Liu, W., Li, W., Yin, W., Meng, M., Wan, Y., Feng, C., Wang, S., and Xi, R. P. (2010) Preparation of a monoclonal antibody and development of an indirect competitive ELISA for the detection of chlorpromazine residue in chicken and swine liver. J. Sci. Food Agric. 90, 1789-1795.

19. Munene, C. N. (2004) Development of chicken polyclonal and mouse monoclonal based enzyme immunoassays for the detection of bbb-cyclocitral in catfish pond water. M.S. Thesis, Louisiana State University, pp 59.

20. Park, S., Shukla, S., Kim, Y., Oh, S., Kim, S. H., and Kim, M. (2012) Development of sandwich enzyme-linked immunosorbent assay for the detection of Cronobacter muytjensii (formerly called Enterobacter sakazakii). Microbiol. Immunol. 56, 472-479.

21. Prakash, B. and Suryanarayana, T. (2005) Evaluation of Salmonella gallinarum outer membrane protein based enzyme linked immunosorbent assay for detecting antibodies in vaccinated and infected chicken. Int. J. Poultry Sci. 4, 222-227.

22. Schneid, A. S., Rodrigues, K. L., Chemello, D. Tondo, E. C., Ayub, M. A. Z., and Aleixo, J. A. G. (2006) Evaluation of an indirect ELISA for the detection of Salmonella in chicken meat. Brazilian J. Microbiol. 37, 350-355.

23. Voller, A. and Bidwell, D. E. (1976) Enzyme immunoassays for antibodies in measles, cytomegalovirus infections and after rubella vaccination. Br. J. Exp. Pathol. 51, 243-247.

24. Wallmann, J. C., Staak, C., and Luge, E. (1990) Einfache method zur isolierung von immunoglobulin (Y) aus Eiern immunisierter Hühner. J. Vet. Med. B 37, 317-320.

(Received 2012.9.20/Revised 2012.10.10/Accepted 2012.10.11) 